\title{
Genomics and Immunity of the Mediterranean mussel Mytilus galloprovincialis in a changing environment
}

\author{
Antonio Figueras*, Rebeca Moreira, Marta Sendra and Beatriz Novoa \\ Institute of Marine Research (IIM), National Research Council (CSIC), Eduardo \\ Cabello, 6, 36208, Vigo, Spain.
}

* Corresponding author

Antonio Figueras

Institute of Marine Research, IIM, National Research Council, CSIC

Eduardo Cabello 6, 36208 Vigo - Spain

Telephone number: +34 986214462 /Fax number: +34 986292762

antoniofigueras@iim.csic.es 


\section{Summary}

The Mediterranean mussel (Mytilus galloprovincialis) is a marine invasive species cultured all over the world. Mussels are an appreciated resource in local aquaculture enterprises because of their robust production and resilience that translates into a reliable economic value. So far, no massive mortalities have been reported in natural or cultured populations of this species. In the last years, the knowledge about its immune system has greatly improved but there are still many questions to be answered. One of them is why mussels, with their high filtering activity, are able to be exposed to a high number of potential pathogens without getting infected and without developing an elevated inflammatory response.

The sequencing of the mussel genome has revealed a very complex organization with high heterozygosity, abundance of repetitive sequences and extreme intraspecific sequence diversity among individuals, mainly in immune related genes. Among those genes, antimicrobial peptides are the most expressed gene families in mussels, highly polymorphic and with antimicrobial effect against molluses pathogens, but also against pathogens of lower vertebrates and humans. The combination of a complex genome with the adaptation of mussel immune system to a changing environment could explain this high variability, not only in immune-related genes, but also in the functional response among individuals sampled in the same location and date.

\section{Keywords}

Mytilus galloprovincialis, immunity, defense, hemocytes, genomics, pollution, environment 


\section{Introduction}

Phylum Mollusca is the second largest animal group and a fossil record of over 540 million years [1]. Molluscs of the Class Bivalvia are present in both marine and freshwater environments. There are infaunal bivalves, attached to substratum (by byssus or cemented), wood and rock- borers, and even predators. This diversity is mainly due to an early evolutive radiation in the Late Cambrian era which allowed bivalves to occupy different ecological niches [2].

Bivalves are economically important as aquaculture resources and as producers of pearls and shells. Moreover, they have an important role in the energy flux in the environment and in the maintenance of the water quality [3]. Given their widespread distribution and their filtrating mode of life, bivalves, specifically mussels, are also important pollution sentinels [4].

In 2016, the world aquaculture production of molluscs reached 17,139,140 tons (excluding products not intended for human consumption) [5]. Aquaculture is the animal production activity with the highest growth rate and its importance for global human feeding steadily grows from year to year. According to FAO, the European production of bivalves is the most important in the world after China. It has a relevant social dimension because most of the companies are micro-enterprises (with less than 10 employees) which hire a high number of employees in this sector [6]. European aquaculture is focused on a limited number of species that are produced at industrial level (mainly mussels, oysters and clams) and it is based on the availability of ecosystems of great environmental quality and food abundance. Mussels are the most produced bivalves in Europe reaching 319,928 tons for M. galloprovincialis and 155,067 tons for M. edulis.

However, bivalve aquaculture is facing a range of risks and limiting factors that include, as other animal production activities, environmental changes, pollution and infectious diseases [7, 8]. Since 2008, high mortalities of the Pacific oyster Crassostrea gigas have been registered in several European countries [9-14]. Herpes virus OsHV-1 combined with adverse environmental factors could be the cause of these high mortalities [15]. As a result, the annual production of Pacific oyster in France went from 110,800 tons in 2007 to 64,000 tons in 2016 [5]. Recently there have been reports of high mortalities of Pacific oyster associated to bacterial infections by Vibrio aestuarianus and also mussel 
mortalities associated to infections by Vibrio splendidus [16]. In fact, it has been reported that the OsHV-1 infection produces an immunosuppression on oysters that evolves towards a fatal bacterial infection caused by opportunistic bacteria [17]. In Galicia (NW Spain), the main producing area of mussels in Europe, the parasite Marteilia cochillia is causing a critical decline of the exploited populations of the cockle Cerastoderma edule [18]. Unfortunately, there are not easy ways to fight against bivalve diseases: as all invertebrates, they do not produce antibodies, therefore it is not possible to vaccinate them and since they are cultured in open sea disease treatments are not possible.

Bivalves use their filtering activity to feed themselves. It has been reported that, on average, mussels can filter about 7,5 liters of water in one hour [19]. This means that they are in permanent contact with millions of potentially pathogenic microorganisms [20]. Stabili et al. (2005) reported that the abundance of Vibrio spp. is higher inside mussels than in the surrounding water [21]. This would explain why bivalves are susceptible to numerous diseases that compromise their culture causing economic losses all over the world. Interestingly, mussels cohabitate in the same areas where oysters cockels and clams have suffered massive mortalities due to viral, bacterial or protozoan infections, however, high mortalities have never been reported in the field for M. galloprovincialis $[14,22]$. This resistance is thought to be linked to the development of a complex and efficient innate immune system, whose cellular and molecular components are progressively being studied and unveiled [23-25].

Despite the role of the immune system in fighting diseases and the efforts of many researchers throughout the world, our knowledge is quite limited. Bivalve immunologists have studied different processes such as phagocytosis, encapsulation, aggregation, prophenol oxidase system, or the release of effective molecules such as oxygen and nitrogen radicals or lysozyme, among others [26-30]. However, it was not until the late 90's, early 2000s when a new set of small molecules with antimicrobial activity was described in bivalves, coinciding with emergent biochemical, molecular biology and sequencing techniques [31-33]. The presence of these antimicrobial peptides (AMPs) has been reported in different bivalve species such as carpet shell clam [34], oyster [35], scallop [36] and mussels [23, 31, 33, 37-41]. Unlike other bivalve species, in which these molecules have been described, a remarkable abundance of these small peptides has been reported for the Mediterranean mussel, M. galloprovincialis [40]. Besides of their 
abundance, AMPs present high genetic variability [42]. These two characteristics, added to the lack of pathogen associated mortalities in this species, could be indicative of a selective evolutionary advantage for mussels.

\section{A complex genome and variable individual transcriptomes}

Next generation sequencing techniques (NGSs) are versatile and constantly evolving tools that have been used in the last decade to uncover the molecular bases of the whole biology of Mytilus galloprovincialis, from development and environmental stress to immune response. In Table 1 we present the transcriptomic and genomic works that have been done since NGSs are available. The cost of these techniques are constantly dropping and, as a consequence, it is expected that in the next years the genomes and transcriptomes of many bivalve species are sequenced.

Although we have already published a draft for the Mediterranean mussel genome [43], its complexity made that we sequenced a new mussel genome with a deeper coverage and sequenced 14 additional individual mussel genomes. This confirmed our suspicions. Mussel genome has a high heterozygosity rate, abundance of repetitive sequences and extreme intraspecific sequence diversity among individuals. A significant number of genes in the reference genome were very variable, but this finding was not explained by the geographical origin or sex of the mussels. Our results suggest that the intraspecific sequence diversity has played a major role in the evolutionary success of mussels, endowing them with a large repertoire of immune receptors and effectors that might have significantly strengthened the social immunity of this bivalve species (Figueras and Gerdol, personal communication). Many open questions remain about the genetic and evolutionary mechanisms underpinning this unique peculiarity and about how this amazing intraspecific diversity is maintained in contemporary populations (Gerdol et al., submitted for publication).

This high variability can be also observed at transcriptomic level [46]. We have demonstrated the great variability among individual transcriptomes in a study using Illumina sequencing of the transcriptome of individual mussels before and after being infected with Vibrio splendidus and how each animal showed an exclusive repertoire of genes not shared with other individuals [67]. In this work, a clear response against the 
injection of filtered seawater was also found, suggesting a reaction against a tissue injury in which the myticins, the most expressed antimicrobial peptides in mussel, appeared significantly up regulated, in contrast with the down-regulation observed after the infection, suggesting that myticins are involved in the response to a danger signal.

Alterations in gene expression due to a pathogenic stimulus lead to changes not only in the immune response but also in the metabolism, the endocrine system and the neural response to stimulus. Today it is of great interest the global study of all these functions and the terms immunometabolism [68] and neuroendocrine immunomodulation [69] are also new research topics in bivalves. Both of them could play relevant roles in key defense processes that still remain unrevealed.

Other interesting aspect of the mussel transcriptome is the high presence of cancer-related genes [55]. Killing and cancer seem to be two of the most frequent gene ontology terms found in mussel transcriptome. Recently, a transmissible cancer has been described in cockles but only rare and sporadic presence of neoplasic cells has been reported in mussels [70-72]. Cockles are cultured close to mussels, but mussels from the species Mytilus galloprovincialis do not seem to be affected by this type of disseminated neoplasia.

\section{Mussel immune system is in permanent contact with microorganisms}

The lack of the classical antibody-based adaptive immunity forced mussels to generate alternative defense strategies to protect themselves. These adaptations allow them to live in a close contact with the big population of microorganisms in the oceans [73] and should avoid an excessive immune reaction against innocuous microorganism but react against potential pathogens. The mucosal immunity is the first line of immune defense, with the external epithelium and mucus acting as a simple physical barrier but also playing a significant immune role [74]. Despite its critical role in immune defense it has not been sufficiently studied. Once this mucosal immune barrier is trespassed, circulating hemocytes in the hemolymph are able to discriminate self from non-self and get rid of potential pathogens. The lack of specific cell markers has prevented, so far, the detailed characterization of the function and the possible differences of specific cell populations. 
In mussel hemocytes, almost half of the expressed genes are antimicrobial peptides [40] being myticins, mytilins, and mytimicins, the most expressed of these AMPs. We already have evidences suggesting that AMPs confer resistance to $M$. galloprovincialis against diseases in contrast to other bivalves: the treatment of oyster hemocytes with mussel hemolymph, or with synthetic myticin C peptides, inhibits the replication of OsHV-1 in oyster hemocytes [75]. Moreover, myticins inhibit the replication of bacteria [76], fish viruses [77] and human herpesvirus [75]. Therefore, myticin $C$ and other bioactive peptides of mussels are examples of the biotechnological and therapeutic potential of this species.

The complexity of bivalve immune responses is also evidenced by the fact that their immune system can be primed, leading to short-term memory. For example, an enhanced cellular immune response has been reported in Crassostrea gigas after a secondary challenge with Vibrio splendidus [78]. Also, recent investigations have shown that experimentally infected juvenile oysters can mount a long-lasting antiviral immune memory that protects them from subsequent viral infections [79]. Furthermore, oysters treated with poly I:C produce offspring with enhanced protection against OsHV-1, suggesting a trans-generational immune priming [80].

In mussels, the study of hemocyte transcriptomes before and after a primary and a secondary sublethal infection with Vibrio splendidus revealed that the first infection significantly regulated genes related to inflammation, migration and response to bacteria. However, after the second infection, the analysis of the differentially expressed genes suggests that mussel hemocytes try to control and resolve the inflammatory response avoiding subsequent cellular death and DNA damage. These results suggest the existence of a modified immune response of mussels after the second challenge oriented to tolerate and not to fight the infection minimizing the tissue damage (Rey Campos et al., submitted for publication).

The specific mechanisms leading to and involved in the immune priming process and also in the transgenerational immune priming are completely unknown, a new frontier in bivalve research. It is probable that regulatory mechanisms of gene expression and translation such as epigenetics and non-coding RNAs may play relevant roles. It is already known that epigenetics alters defense response and development in bivalves [81, 82], and it has been recently published the mechanism to generate small RNAs in mussels and 
oysters by Rosani et al. [83]. These non-coding RNAs can alter, among other physiological processes, the immune response $[84,85]$. Both, epigenetics and non-coding RNAs, are current challenges in bivalve research which will deliver interesting results in the next years.

\section{Mussel immunity is altered by the anthropogenic influence in the environment}

Global climatic change and the increasing level of new pollutants such as micro and nanoparticles are already influencing bivalve homeostasis in a way never experienced before. For example, micro (smaller than $5 \mathrm{~mm}$ ) and nanoparticles (smaller than 100nm) of diverse origin have been shown to disrupt mussel metabolism, microbiota and immune function, increasing the expression of genes related to stress, and resulting in a decrease of energy allocated to growth $[8,86,87]$.

The "mussel watch" project is an international pollution monitoring program that propose mussels as bioindicators of classical and emergent pollutants such as nanomaterials, personal care products and drugs [88, 89]. Due to their wide distribution, sessile status and the occupation of vital ecological niches, mussels are a proper tool to monitor contaminants of emerging concern. Bivalve immune system is a target for the effects of nanomaterials due to the efficient immunological system against non-self-particles and the internalization of nano and microparticles by hemocytes [86, 89]. In vitro assays with mussel hemocytes to test emerging pollutants are recent and powerful tools which allow a fast screening of their immunomodulatory effects and the identification of mechanistic pathways such as reactivity, inflammation and cellular uptake of emergent pollutants [90, 91]. Furthermore, in vitro ecotoxicological tests with hemocytes are easily reproducible under controlled conditions, and they are the cornerstone of nanotoxicological studies [92-94]. Another advantage of in vitro assays with mussel hemocytes is the similar behavior with human cells. In the study by Katsumity et al. (2018), M. galloprovincialis hemocytes and lung human cell line TT1 showed similar sensitivity to $\mathrm{CuO}$ nanoparticles exposure, reaching up similar levels of ROS production [95]. The limitation of the in vitro assays is that they need to be validated for their relevance for in vivo hazard [96].

In addition to their toxic properties, the nanoparticles suspended in environmental and biological matrixes acquire secondary properties [97]. The negative zeta potential of 
nanoparticles is key in the formation of the protein-corona when they are suspended in hemolymph serum $[89,98]$. The protein-corona, possess long-term stability in biological environments, making the nanoparticles able to interact with membrane receptors, particle wrapping, trafficking, cellular uptake and immune responses [86, 99].

Another challenge for the scientific community is the detection of early warning toxicity and to understand complex effects in the specific pathways that could be affected. The molecular and -omic approaches are powerful tools to figure out the mechanisms leading to the response and the adaptation of bivalves to environmental changes [51]. Table 2 shows several toxicological studies with mussels exposed to pollutants of emerging concern applying different molecular and -omic approaches. Of note is the study by Détrée and Gallardo-Escárate [8] that demonstrated stress-memory in mussels after a second exposure of microplastics. It highlights, once again, the complexity of the innate immune system of bivalves.

All these antecedents should led researchers to be aware that bivalve immune response is strongly influenced by this new pollution source. More attention should be paid to the interaction of this insidious new scenario and its impact on bivalve immune system function and resilience.

\section{Conclusions and future perspectives}

Our intention in this article was not to conduct an exhaustive review of genomics and immunology of bivalves, or specifically mussels, but to offer an overview of some interesting aspects that we found studying the immune response of these animals. As stated in Rey-Campos et al. (2019) «Currently, we undoubtedly can say that mussels are anything but simple and that more revelations will appear in the study of "non-model mussel immunity"».

\section{Acknowledgements}

This work was conducted with the support of the projects AGL2015-65705-R (Ministerio de Economía y Competitividad, Spain) and VIVALDI (678589) (EU H2020). MS also 
wants to acknowledge the Spanish Ministerio de Ciencia, Innovación y Universidades for her Juan de la Cierva contract (TJFI-2017-32493).

\section{Competing Interests}

The authors declare no competing interests. 


\section{References}

1. Ponder W, Lindberg DR. Phylogeny and evolution of the Mollusca. University of California Press, Oakland, 2008

2. Plazzi F, Passamonti M. Towards a molecular phylogeny of mollusks: bivalves' early evolution as revealed by mitochondrial genes. Mol Phylogenet Evol 2010; 57:641-657

3. Giles H, Pilditch CA, Bell DG. Sedimentation from mussel (Perna canaliculus) culture in the Firth of Thames, New Zealand: impacts on sediment oxygen and nutrient fluxes. Aquaculture 2006; 261:125-140

4. Farrington JW, Tripp BW, Tanabe S, et al Edward D. Goldberg's proposal of "the Mussel Watch": Reflections after 40years. Mar Pollut Bull 2016; 110:501-510. doi: 10.1016/j.marpolbul.2016.05.074

5. FAO. 2018. FAO yearbook. Fishery and Aquaculture Statistics 2016. Rome

6. JRC Scientific and Policy Reports. 2013. European Commission Joint Research Centre. Luxembourg: Publications Office of the European Union 2013

7. Aranguren R, Figueras A. Moving from Histopathology to Molecular Tools in the Diagnosis of Molluscs Diseases of Concern under EU Legislation. Front Physiol 2016; 7:538

8. Détrée C, Gallardo-Escárate C. Single and repetitive microplastics exposures induce immune system modulation and homeostasis alteration in the edible mussel Mytilus galloprovincialis. Fish Shellfish Immuno 2018; 83:52-60

9. Segarra A, Pepin JF, Arzul I, Morga B, Faury N, Renault T. Detection and description of a particular Ostreid herpesvirus 1 genotype associated with massive mortality outbreaks of Pacific oysters, Crassostrea gigas, in France in 2008. Virus Res 2010; 153:92-99

10. Martenot C, Oden E, Travaillé E, Malas JP, Houssin M. Detection of different variants of Ostreid Herpesvirus 1 in the Pacific oyster, Crassostrea gigas between 2008 and 2010. Virus Res 2011; 160:25-31. doi: 10.1016/j.virusres.2011.04.012

11. Lynch SA, Carlsson J, Reilly AO, Cotter E, Culloty SC. A previously undescribed ostreid herpes virus 1 (OsHV-1) genotype detected in the pacific oyster, Crassostrea gigas, in Ireland. Parasitology 2012; 139:1526-32. doi: 10.1017/S0031182012000881

12. Peeler EJ, Reese RA, Cheslett DL, Geoghegan F, Power A, Thrush MA. Investigation of mortality in Pacific oysters associated with Ostreid herpesvirus- $1 \mu$ Var in the Republic of Ireland in 2009. Prev Vet Med 2012; 105:136-43. doi: 10.1016/j.prevetmed.2012.02.001

13. Garcia C, Thébault A, Dégremont L, Arzul I, Miossec L, Robert M, Chollet B, François C, Joly JP, Ferrand S, Kerdudou N, Renault T. Ostreid herpesvirus 1 detection and relationship with Crassostrea gigas spat mortality in France between 1998 and 2006. Vet Res 2011; 42:73. doi: 10.1186/1297-9716-42-73

14. Domeneghetti S, Varotto L, Civettini M, Rosani U, Stauder M, Pretto T, Pezzati E, Arcangeli G, Turolla E, Pallavicini A, Venier P. Mortality occurrence and pathogen detection in Crassostrea gigas and Mytilus galloprovincialis close-growing in shallow waters (Goro lagoon, Italy). Fish Shellfish Immunol 2014; 41:37-44. doi: 10.1016/j.fsi.2014.05.023 
15. Davison AJ, Trus BL, Cheng N, Steven AC, Watson MS, Cunningham C, Le Deuff RM, Renault T. A novel class of herpesvirus with bivalve hosts. J Gen Virol 2005; $86: 41-53$

16. Ben Cheikh Y, Travers MA, Morga B, Godfrin Y, Rioult D, Le Foll F. First evidence for a Vibrio strain pathogenic to Mytilus edulis altering hemocyte immune capacities. Dev Comp Immunol 2016; 57:107-19. doi: 10.1016/j.dci.2015.12.014

17. de Lorgeril J, Lucasson A, Petton B, Toulza E, Montagnani C, Clerissi C, Vidal-Dupiol J, Chaparro C, Galinier R, Escoubas JM, Haffner P, Dégremont L, Charrière GM, Lafont M, Delort A, Vergnes A, Chiarello M, Faury N, Rubio T, Leroy MA, Pérignon A, Régler D, Morga B, Alunno-Bruscia M, Boudry P, Le Roux F, DestoumieuxGarzón D, Gueguen Y, Mitta G. Immune-suppression by OsHV-1 viral infection causes fatal bacteraemia in Pacific oysters. Nat Commun 2018; 9:4215. doi: 10.1038/s41467-018-06659-3

18. Villalba A, Iglesias D, Ramilo A, Darriba S, Parada JM, No E, Abollo E, Molares J, Carballal MJ. Cockle Cerastoderma edule fishery collapse in the Ría de Arousa (Galicia, NW Spain) associated with the protistan parasite Marteilia cochillia. Dis Aquat Organ 2014; 109:55-80. doi: 10.3354/dao02723

19. Cole BE, Thompson JK, Cloern JE. Measurement of filtration rates by infaunal bivalves in a recirculating flume. Mar Biol 1992; 113:219-225

20. Suttle CA. Marine viruses - major players in the global ecosystem. Nat Rev Microbiol 2007; 5:801-812

21. Stabili L, Acquaviva MI, Cavallo RA. Mytilus galloprovincialis filter feeding on the bacterial community in a Mediterranean coastal area (Northern Ionian Sea, Italy). Water Res 2005; 39:469-77

22. Romero A, Costa Md, Forn-Cuni G, Balseiro P, Chamorro R, Dios S, Figueras A, Novoa B. Occurrence, seasonality and infectivity of Vibrio strains in natural populations of mussels Mytilus galloprovincialis. Dis Aquat Organ 2014; 108:149-163

23. Venier P, Varotto L, Rosani U, Millino C, Celegato B, Bernante F, Lanfranchi G, Novoa B, Roch P, Figueras A, Pallavicini A. Insights into the innate immunity of the Mediterranean mussel Mytilus galloprovincialis. BMC Genomics 2011; 12:69. doi: 10.1186/1471-2164-12-69

24. Gerdol M, Venier P. An updated molecular basis for mussel immunity. Fish Shellfish Immunol 2015; 46:17-38

25. Gerdol M, Gomez-Chiarri M, Castillo MG, Figueras A, Fiorito G, Moreira R, Novoa B, Pallavicini A, Ponte G, Roumbedakis K, Venier P, Vasta GR. Immunity in Molluscs: Recognition and Effector Mechanisms, with a Focus on Bivalvia. In: Advances in Comparative Immunology 2018; Ed. Edwin Cooper. Springer.

26. Carballal MJ, López MC, Azevedo C, Villalba A. Hemolymph cell types of the mussel Mytilus galloprovincialis. Dis Aquat Organ 1997; 29:127-135

27. Ratcliffe NA, Rowley AF, Fitzgerald SW, Rhodes CP. Invertebrate immunity: basic concepts and recent advances. Int Rev Cytol 1985; 97:183-350

28. Torreilles J, Guérin MC, Roch P. Reactive oxygen species and defense mechanisms in marine bivalves. C R Acad Sci III 1996; 319:209-218

29. Tafalla C, Novoa B, Figueras A. Production of nitric oxide by mussel (Mytilus 
galloprovincialis) hemocytes and effect of exogenous nitric oxide on phagocytic functions. Comp Biochem Physiol B Biochem Mol Biol. 2002; 132:423-431.

30. Costa MM, Prado-Alvarez M, Gestal C, Li H, Roch P, Novoa B, Figueras A. Functional and molecular immune response of Mediterranean mussel (Mytilus galloprovincialis) haemocytes against pathogen-associated molecular patterns and bacteria. Fish Shellfish Immunol 2009; 26:515-523.

31. Hubert F, Noel T, Roch P. A member of the arthropod defensin family from edible Mediterranean mussels (Mytilus galloprovincialis). Eur J Biochem 1996; 240:302-306

32. Mitta G, Vandenbulcke F, Hubert F, Roch P. Mussel defensins are synthesised and processed in granulocytes then released into the plasma after bacterial challenge. J Cell Sci 1999; 112:4233-4242

33. Mitta G, Hubert F, Noël T, Roch P. Myticin, a novel cysteine-rich antimicrobial peptide isolated from haemocytes and plasma of the mussel Mytilus galloprovincialis. Eur J Biochem 1999; 265:71-78

34. Gestal C, Costa M, Figueras A, Novoa B. Analysis of differentially expressed genes in response to bacterial stimulation in hemocytes of the carpet shell clam Ruditapes decussatus: identification of new antimicrobial peptides. Gene 2007; 406:134-143

35. Seo JK, Crawford JM, Stone KL, Noga EJ. Purification of a novel arthropod defensin from the American oyster, Crassostrea virginica. Biochem Biophys Res Commun 2005; 338:1998-2004.

36. Zhao J, Song L, Li C, Ni D, Wu L, Zhu L, Wang H, Xu W. Molecular cloning, expression of a big defensin gene from bay scallop Argopecten irradians and the antimicrobial activity of its recombinant protein. Mol Immunol 2007; 44:360-368.

37. Charlet M, Chernysh S, Philippe H, Hetru C, Hoffmann JA, Bulet P. Innate immunity. Isolation of several cysteine-rich antimicrobial peptides from the blood of a mollusc, Mytilus edulis. J Biol Chem 1996; 271:21808-21813.

38. Mitta G, Vandenbulcke F, Noël T, Romestand B, Beauvillain JC, Salzet M, Roch P. Differential distribution and defence involvement of antimicrobial peptides in mussel. J Cell Sci 2000; 113:2759-2769.

39. Mitta G, Vandenbulcke F, Roch P. Original involvement of antimicrobial peptides in mussel innate immunity. FEBS Lett 2000; 486:185-190

40. Pallavicini A, del Mar Costa M, Gestal C, Dreos R, Figueras A, Venier P, Novoa B. High sequence variability of myticin transcripts in hemocytes of immune-stimulated mussels suggests ancient host-pathogen interactions. Dev Comp Immunol 2008; 32:213-226

41. Gerdol M, De Moro G, Manfrin C, Venier P, Pallavicini A. Big defensins and mytimacins, new AMP families of the Mediterranean mussel Mytilus galloprovincialis. Dev Comp Immunol 2012; 36:390-399. doi: 10.1016/j.dci.2011.08.003

42. Costa MM, Dios S, Alonso-Gutierrez J, Romero A, Novoa B, Figueras A. Evidence of high individual diversity on myticin $\mathrm{C}$ in mussel (Mytilus galloprovincialis). Dev Comp Immunol 2009; 33:162-170

43. Murgarella M, Puiu D, Novoa B, Figueras A, Posada D, Canchaya C. A first insight into the genome of the filter-feeder mussel Mytilus galloprovincialis. PLoS One 2016; 


\section{1:e0151561}

44. Nguyen TTT, Hayes BJ, Ingram BA. Genetic parameters and response to selection in blue mussel (Mytilus galloprovincialis) using a SNP-based pedigree. Aquaculture 2014; 420-421:295-301. doi: 10.1016/j.aquaculture.2013.11.021

45. Rosani U, Domeneghetti S, Pallavicini A, Venier P. Target capture and massive sequencing of genes transcribed in Mytilus galloprovincialis. Biomed Res Int. 2014; 2014:538549. doi: 10.1155/2014/538549

46. Lockwood BL, Sanders JG, Somero GN. Transcriptomic responses to heat stress in invasive and native blue mussels (genus Mytilus): molecular correlates of invasive success. J Exp Biol 2010; 213:3548-3558. doi: 10.1242/jeb.046094

47. Venier P, De Pittà C, Pallavicini A, Marsano F, Varotto L, Romualdi C, Dondero F, Viarengo A, Lanfranchi G. Development of mussel mRNA profiling: Can gene expression trends reveal coastal water pollution? Mutat Res 2006; 602:121-134

48. Craft JA, Gilbert JA, Temperton B, Dempsey KE, Ashelford K, Tiwari B, Hutchinson TH, Chipman JK. Pyrosequencing of Mytilus galloprovincialis cDNAs: tissue-specific expression patterns. PLoS One 2010; 5:e8875. doi: 10.1371/journal.pone.0008875

49. Lockwood BL, Somero GN. Transcriptomic responses to salinity stress in invasive and native blue mussels (genus Mytilus). Mol Ecol. 2011; 20:517-529. doi: 10.1111/j.1365-294X.2010.04973.x

50. Rosani U, Varotto L, Rossi A, Roch P, Novoa B, Figueras A, Pallavicini A, Venier P. Massively parallel amplicon sequencing reveals isotype-specific variability of antimicrobial peptide transcripts in Mytilus galloprovincialis. PLoS One 2011; 6:e26680

51. Suárez-Ulloa V, Fernández-Tajes J, Manfrin C, Gerdol M, Venier P, Eirín-López J. Bivalve omics: state of the art and potential applications for the biomonitoring of harmful marine compounds. Mar Drugs 2013; 11:4370-4389

52. Negri A, Oliveri C, Sforzini S, Mignione F, Viarengo A, Banni M. Transcriptional response of the mussel Mytilus galloprovincialis (Lam.) following exposure to heat stress and copper. PLoS One. 2013; 8:e66802. doi: 10.1371/journal.pone.0066802

53. Mohamed B, Hajer A, Susanna S, Caterina O, Flavio M, Hamadi B, Aldo V. Transcriptomic responses to heat stress and nickel in the mussel Mytilus galloprovincialis. Aquat Toxico. 2014; 148:104-12. doi: 10.1016/j.aquatox.2014.01.004

54. Gerdol M, De Moro G, Manfrin C, Milandri A, Riccardi E, Beran A, Venier P, Pallavicini A. RNA sequencing and de novo assembly of the digestive gland transcriptome in Mytilus galloprovincialis fed with toxinogenic and non-toxic strains of Alexandrium minutum. BMC Res Notes 2014; 7:722. doi: 10.1186/1756-0500-7722

55. Moreira R, Pereiro P, Canchaya C, Posada D, Figueras A, Novoa B. RNA-Seq in Mytilus galloprovincialis: comparative transcriptomics and expression profiles among different tissues. BMC Genomics 2015; 16:728

56. Banni M, Sforzini S, Balbi T, Corsi I, Viarengo A, Canesi L. Combined effects of n$\mathrm{TiO} 2$ and 2,3,7,8-TCDD in Mytilus galloprovincialis digestive gland: A transcriptomic and immunohistochemical study. Environ Res 2016; 145:135-144. doi: 
10.1016/j.envres.2015.12.003

57. Bjärnmark NA, Yarra T, Churcher AM, Felix RC, Clark MS, Power DM. Transcriptomics provides insight into Mytilus galloprovincialis (Mollusca: Bivalvia) mantle function and its role in biomineralisation. Mar Genomics. 2016; 27:37-45. doi: 10.1016/j.margen.2016.03.004

58. Maria VL, Amorim MJ, Bebianno MJ, Dondero F. Transcriptomic effects of the nonsteroidal anti-inflammatory drug Ibuprofen in the marine bivalve Mytilus galloprovincialis Lam. Mar Environ Res 2016; 119:31-39. doi: 10.1016/j.marenvres.2016.05.010

59. Mezzelani M, Gorbi S, Fattorini D, d'Errico G, Benedetti M, Milan M, Bargelloni L, Regoli F. Transcriptional and cellular effects of Non-Steroidal Anti-Inflammatory Drugs (NSAIDs) in experimentally exposed mussels, Mytilus galloprovincialis. Aquat Toxicol. 2016; 180:306-319. doi: 10.1016/j.aquatox.2016.10.006

60. Banni M, Sforzini S, Arlt VM, Barranger A, Dallas LJ, Oliveri C, Aminot Y, Pacchioni B, Millino C, Lanfranchi G, Readman JW, Moore MN, Viarengo A, Jha AN. Assessing the impact of Benzo[a]pyrene on Marine Mussels: Application of a novel targeted low density microarray complementing classical biomarker responses. PLoS One. 2017; 12:e0178460. doi: 10.1371/journal.pone.0178460

61. Saarman NP, Kober KM, Simison WB, Pogson GH. Sequence-Based Analysis of Thermal Adaptation and Protein Energy Landscapes in an Invasive Blue Mussel (Mytilus galloprovincialis). Genome Biol Evol. 2017; 9:2739-2751. doi: 10.1093/gbe/evx190

62. Pazos AJ, Ventoso P, Martínez-Escauriaza R, Pérez-Parallé ML, Blanco J, Triviño JC, Sánchez JL. Transcriptional response after exposure to domoic acid-producing Pseudo-nitzschia in the digestive gland of the mussel Mytilus galloprovincialis. Toxicon. 2017; 140:60-71. doi: 10.1016/j.toxicon.2017.10.002

63. Moreira R, Balseiro P, Forn-Cuní G, Milan M, Bargelloni L, Novoa B, Figueras A. Bivalve transcriptomics reveal pathogen sequences and a powerful immune response of the Mediterranean mussel (Mytilus galloprovincialis). Mar Biol 2018; 165:61

64. Mezzelani M, Gorbi S, Fattorini D, d'Errico G, Consolandi G, Milan M, Bargelloni L, Regoli F. Long-term exposure of Mytilus galloprovincialis to diclofenac, Ibuprofen and Ketoprofen: Insights into bioavailability, biomarkers and transcriptomic changes. Chemosphere 2018; 198:238-248. doi: 10.1016/j.chemosphere.2018.01.148

65. Moreira R, Pereiro P, Balseiro P, Milan M, Pauletto M, Bargelloni L, Novoa B, Figueras A. Revealing Mytilus galloprovincialis transcriptomic profiles during ontogeny. Dev Comp Immunol 2018; 84:292-306. doi: 10.1016/j.dci.2018.01.016

66. Prego-Faraldo MV, Martínez L, Méndez J. RNA-Seq Analysis for Assessing the Early Response to DSP Toxins in Mytilus galloprovincialis Digestive Gland and Gill. Toxins (Basel) 2018; 10:pii:E417. doi: 10.3390/toxins10100417

67. Rey-Campos M, Moreira R, Valenzuela-Muñoz V, Gallardo-Escárate C, Novoa B, Figueras A. High individual variability in the transcriptomic response of Mediterranean mussels to Vibrio reveals the involvement of myticins in tissue injury. Sci Rep 2019; 9:3569. doi: 10.1038/s41598-019-39870-3

68. Penkov S, Mitroulis I, Hajishengallis G, Chavakis T. Immunometabolic crosstalk: an 
ancestral principle of trained immunity? Trends Immunol 2019; 40:1-11. doi: 10.1016/j.it.2018.11.002

69. Liu Z, Zhou Z, Jiang Q, Wang L, Yi Q, Qiu L, Song L. The neuroendocrine immunomodulatory axis-like pathway mediated by circulating haemocytes in pacific oyster Crassostrea gigas. Open Biol 2017; 7(1):160289

70. Carella F, Figueras A, Novoa B, De Vico G. Comparative cytomorphological features and PCNA expression pattern in Haemic Neoplasia from mediterranean mussels (Mytilus galloprovincialis) and Galician common cockles (Cerastoderma edule). Dis Aquat Organ 2013; 105:81-87

71. Arriagada G, Metzger MJ, Muttray AF, Sherry J, Reinisch C, Street C, Lipkin WI, Goff SP. Activation of transcription and retrotransposition of a novel retroelement, Steamer, in neoplastic hemocytes of the mollusk Mya arenaria. Proc Natl Acad Sci U S A 2014; 111:14175-14180.

72. Metzger MJ, Villalba A, Carballal MJ, Iglesias D, Sherry J, Reinisch C, Muttray AF, Baldwin SA, Goff SP. Widespread transmission of independent cancer lineages within multiple bivalve species. Nature 2016; 534:705-709.

73. Giovannoni SJ, Stingl U. Molecular diversity and ecology of microbial plankton. Nature 2005; 437:343-348

74. Allam B, Pales Espinosa E. Bivalve immunity and response to infections: are we looking at the right place? Fish Shellfish Immunol 2016; 53:4-12

75. Novoa B, Romero A, Álvarez ÁL, Moreira R, Pereiro P, Costa MM, Dios S, Estepa A, Parra F, Figueras A. Antiviral activity of myticin C peptide from mussel: an ancient defence against herpesviruses. J Virol 2016; 90:7692-7702

76. Martinez-Lopez A, Encinar JA, Medina-Gali RM, Balseiro P, Garcia-Valtanen P, Figueras A, Novoa B, Estepa A. pH-dependent solution structure and activity of a reduced form of the host-defense peptide myticin C (Myt C) from the mussel Mytilus galloprovincialis. Mar Drugs 2013; 11:2328-2346. doi: 10.3390/md11072328

77. Balseiro P, Falcó A, Romero A, Dios S, Martínez-López A, Figueras A, Estepa A, Novoa B. Mytilus galloprovincialis myticin C: a chemotactic molecule with antiviral activity and immunoregulatory properties. PLoS One 2011; 6:e23140

78. Zhang T, Qiu L, Sun Z, Wang L, Zhou Z, Liu R, Yue F, Sun R, Song L. The specifically enhanced cellular immune responses in Pacific oyster (Crassostrea gigas) against secondary challenge with Vibrio splendidus. Dev Comp Immunol 2014; 45:141-150

79. Lafont M, Petton B, Vergnes A, Pauletto M, Segarra A, Gourbal B, Montagnani C. Long-lasting antiviral innate immune priming in the Lophotrochozoan Pacific oyster, Crassostrea gigas. Sci Rep 2017; 7:13143. doi: 10.1038/s41598-017-13564-0.

80. Green TJ, Helbig K, Speck P, Raftos DA. Primed for success: oyster parents treated with poly (I:C) produce offspring with enhanced protection against Ostreid herpesvirus type I infection. Mol Immunol 2016; 78:113-120

81. Farias ND, de Oliveira NFP, da Silva PM. Perkinsus infection is associated with alterations in the level of global DNA methylation of gills and gastrointestinal tract of the oyster Crassostrea gasar. J Invertebr Pathol. 2017; 149:76-81. doi: 10.1016/j.jip.2017.08.007.

82. Riviere G, He Y, Tecchio S, Crowell E, Gras M, Sourdaine P, Guo X, Favrel P. 
Dynamics of DNA methylomes underlie oyster development. PLoS Genet 2017; 13 https://doi.org/10.1371/journal.pgen.1006807 e1006807

83. Rosani U, Pallavicini A, Venier P. The miRNA biogenesis in marine bivalves. PeerJ 2016; 4:e1763. doi: 10.7717/peerj.1763

84. Burgos-Aceves MA, Cohen A, Smith Y, Faggio C. A potential microRNA regulation of immune-related genes in invertebrate haemocytes. Sci Total Environ 2018; 621:302-307. doi: 10.1016/j.scitotenv.2017.11.285

85. Huang XD, Dai JG, Lin KT, Liu M, Ruan HT, Zhang H, Liu WG, He MX, Zhao M. Regulation of IL-17 by lncRNA of IRF-2 in the pearl oyster. Fish Shellfish Immunol 2018; 81:108-112. doi: 10.1016/j.fsi.2018.07.020.

86. Canesi L, Ciacci C, Bergami E, Monopoli MP, Dawson KA, Papa S, Canonico B, Corsi, I. Evidence for immunomodulation and apoptotic processes induced by cationic polystyrene nanoparticles in the hemocytes of the marine bivalve Mytilus. Mar Environ Res 2015; 111:34-40.

87. Auguste M, Lasa A, Pallavicini A, Gualdi S, Vezzulli L, Canesi, L. Exposure to TiO2 nanoparticles induces shifts in the microbiota composition of Mytilus galloprovincialis hemolymph. Sci Total Environ 2019; 670:129-137.

88. Goldberg ED. The mussel watch: a first step in global marine monitoring. Mar Pollut Bull 1975; 6:111-114

89. Canesi L, Corsi I. Effects of nanomaterials on marine invertebrates. Sci Total Environ 2016; 565:933-940.

90. SCENIHR working group. The appropriateness of the risk assessment methodology in accordance with the technical guidance documents for new and existing substances for assessing the risks of nanomaterials. Brussels, Belgium: European Commission. 2007 Brussels

91. Canesi L, Ciacci C, Fabbri R, Marcomini A, Pojana G, Gallo G. Bivalve molluscs as a unique target group for nanoparticle toxicity. Mar Environ Res 2012; 76:16-21.

92. Nel A, Xia T, Mädler L, Li N. Toxic potential of materials at the nanolevel. Science 2006; 311:622-627

93. Service RF. Nanotechnology. Can high-speed tests sort out which nanomaterials are safe? Science 2008; 321:1036

94. Shaw SY, Westly EC, Pittet MJ, Subramanian A, Schreiber SL, Weissleder R. Perturbational profiling of nanomaterial biologic activity. P Nat Acad Sci 2008; 105:7387-7392.

95. Katsumiti A, Thorley AJ, Arostegui I, Reip P, Valsami-Jones E, Tetley TD, Cajaraville MP. Cytotoxicity and cellular mechanisms of toxicity of CuO NPs in mussel cells in vitro and comparative sensitivity with human cells. Toxicol In Vitro 2018; 48:146-158

96. Henshaw DL, O'Carroll MJ. Scientific Committee on Emerging and Newly Identified Health Risks (SCENIHR). Brussels: European Commission 2009

97. Monopoli MP, Bombelli FB, Dawson KA. Nanobiotechnology: nanoparticle coronas take shape. Nat Nanotechnol 2011; 6:11

98. Canesi L, Balbi T, Fabbri R, Salis A, Damonte G, Volland M. Blasco J. Biomolecular coronas in invertebrate species: implications in the environmental impact of nanoparticles. NanoImpact 2017; 8:89-98 
99. Fleischer CC, Payne CK. Nanoparticle-cell interactions: molecular structure of the protein corona and cellular outcomes. Accounts Chem Res 2014; 47:2651-2659.

100. Tedesco S, Doyle H, Blasco J, Redmond G, Sheehan D. Oxidative stress and toxicity of gold nanoparticles in Mytilus edulis. Aquat Toxicol 2010; 100:178-186.

101. Gomes T, Pereira CG, Cardoso C, Bebianno MJ. Differential protein expression in mussels Mytilus galloprovincialis exposed to nano and ionic Ag. Aquat Toxicol 2013; 136:79-90.

102. D'Agata A, Fasulo S, Dallas LJ, Fisher AS, Maisano M, Readman JW, Jha AN. Enhanced toxicity of 'bulk'titanium dioxide compared to fresh and aged nano-TiO2 in marine mussels (Mytilus galloprovincialis). Nanotoxicology 2014; 8:549-558

103. $\mathrm{Hu}$ W, Culloty S, Darmody G, Lynch S, Davenport J, Ramirez-Garcia S, Dawson KA, Lynch I, Blasco J, Sheehan D. Toxicity of copper oxide nanoparticles in the blue mussel, Mytilus edulis: a redox proteomic investigation. Chemosphere 2014; 108:289299.

104. Bebianno MJ, Gonzalez-Rey M, Gomes T, Mattos JJ, Flores-Nunes F, Bainy ACD. Is gene transcription in mussel gills altered after exposure to Ag nanoparticles? Environ Sci Pollut Res 2015; 22:17425-17433.

105. Châtel A, Lièvre C, Barrick A, Bruneau M, Mouneyrac C. Transcriptomic approach: A promising tool for rapid screening nanomaterial-mediated toxicity in the marine bivalve Mytilus edulis-Application to copper oxide nanoparticles. Comp Biochem Phys C 2018; 205:26-33

106. Green DS, Colgan TJ, Thompson RC, Carolan JC. Exposure to microplastics reduces attachment strength and alters the haemolymph proteome of blue mussels (Mytilus edulis). Environ Pollut 2019; 246:423-434 
Table 1. Genomic and transcriptomic works published for Mytilus galloprovincialis.

\begin{tabular}{|c|c|c|c|}
\hline Sequencing & NGS technique & Tissue & Reference \\
\hline $\begin{array}{l}\text { Genome (high } \\
\text { quality) }\end{array}$ & $\begin{array}{l}\text { Illumina HiSeq2000 } \\
\text { paired end and mate pair } \\
\text { Fosmid library } \\
\text { PacBio } \\
\end{array}$ & Mantle & Gerdol et al., submitted \\
\hline $\begin{array}{l}\text { Genome (low } \\
\text { quality) }\end{array}$ & Illumina HiSeq2000 & Muscle & $\begin{array}{l}\text { [43] Murgarella et al., } \\
2016\end{array}$ \\
\hline $\begin{array}{l}\text { Genome (low } \\
\text { quality) }\end{array}$ & Illumina HiSeq 2000 & Mantle & [44] Nguyen et al., 2014 \\
\hline Genome (partial) & $\begin{array}{c}\text { Targeted } 454 \\
\text { pyrosequencing }\end{array}$ & Foot & [45] Rosani et al., 2014 \\
\hline Transcriptome & $\begin{array}{c}2 \times 105 \mathrm{~K} \text { Agilent oligo- } \\
\text { DNA microarray }\end{array}$ & Gill & $\begin{array}{l}\text { [46] Lockwood et al., } \\
2010\end{array}$ \\
\hline Transcriptome & Mytarray V1.0 & $\begin{array}{c}\text { Gill, digestive gland, } \\
\text { foot/adductor muscle/ligaments } \\
\text { and mantle/gonad }\end{array}$ & [47] Venier et al., 2006 \\
\hline Transcriptome & 454 pyrosequencing & $\begin{array}{l}\text { Gigestive gland, foot, gill and } \\
\text { mantle }\end{array}$ & [48] Craft et al., 2010 \\
\hline Transcriptome & $\begin{array}{c}2 \times 105 \text { K Agilent oligo- } \\
\text { DNA microarray }\end{array}$ & Gill & $\begin{array}{l}\text { [49] Lockwood and } \\
\text { Somero, } 2011\end{array}$ \\
\hline Transcriptome & $\begin{array}{c}\text { Targeted } 454 \\
\text { pyrosequencing }\end{array}$ & Hemocytes & [50] Rosani et al., 2011 \\
\hline Transcriptome & 454 pyrosequencing & Digestive gland & $\begin{array}{l}\text { [51] Suárez-Ulloa et al., } \\
2013\end{array}$ \\
\hline Transcriptome & Mytarray V1.1 & Females digestive gland & [52] Negri et al., 2013 \\
\hline Transcriptome & Mytarray V1.1 & Females digestive gland & $\begin{array}{l}\text { [53] Mohamed et al., } \\
2014\end{array}$ \\
\hline Transcriptome & Illumina GAII & Digestive gland & [54] Gerdol et al., 2014 \\
\hline Transcriptome & Illumina HiSeq 2000 & Hemocytes, muscle, mantle, gill & [55] Moreira et al., 2015 \\
\hline Transcriptome & Mytarray V1.1 & Digestive gland & [56] Banni et al., 2016 \\
\hline Transcriptome & Illumina HiSeq 1500 & Mantle edge & $\begin{array}{c}\text { [57] Bjärnmark et al., } \\
2016\end{array}$ \\
\hline Transcriptome & Mytarray V1.1 & Females digestive gland & [58] Maria et al., 2016 \\
\hline Transcriptome & $\begin{array}{c}8 \times 60 \mathrm{~K} \text { Agilent oligo- } \\
\text { DNA microarray }\end{array}$ & Whole animal & $\begin{array}{l}\text { [59] Mezzelani et al., } \\
2016\end{array}$ \\
\hline Transcriptome & $\begin{array}{l}\text { Low-density Agilent } \\
\text { microarray }\end{array}$ & Digestive gland and gill & [60] Banni et al., 2017 \\
\hline Transcriptome & Illumina HiSeq & Whole animal & $\begin{array}{c}\text { [61] Saarman et al., } \\
2017\end{array}$ \\
\hline Transcriptome & Illumina HiSeq 2000 & Digestive gland & [62] Pazos et al., 2017 \\
\hline Transcriptome & 454 pyrosequencing & Hemocytes & [63] Moreira et al., 2018 \\
\hline Transcriptome & $\begin{array}{c}8 \times 60 \mathrm{~K} \text { Agilent oligo- } \\
\text { DNA microarray }\end{array}$ & Digestive gland & $\begin{array}{c}\text { [64] Mezzelani et al., } \\
2018\end{array}$ \\
\hline Transcriptome & $\begin{array}{c}8 \times 60 \mathrm{~K} \text { Agilent oligo- } \\
\text { DNA microarray }\end{array}$ & Oocytes and larval stages & [65] Moreira et al., 2018 \\
\hline Transcriptome & Illumina HiSeq 2000 & Digestive gland and gill & $\begin{array}{l}\text { [66] Prego-Faraldo et al., } \\
2018\end{array}$ \\
\hline Transcriptome & Illumina HiSeq 2000 & Mantle and digestive gland & $\begin{array}{c}\text { [8] Détrée and Gallardo- } \\
\text { Escárate, } 2018\end{array}$ \\
\hline Transcriptome & Illumina HiSeq4000 & Hemocytes & $\begin{array}{l}\text { [67] Rey-Campos et al., } \\
2019\end{array}$ \\
\hline
\end{tabular}


Table 2. Molecular and -omic techniques applied to toxicological studies with mussels and pollutants of emerging concern.

\begin{tabular}{|c|c|c|c|c|}
\hline Species & Pollutant & Technique & Results & Reference \\
\hline M. edulis & $\mathrm{Au}$ NPs & 1-DE, 2-DE & $\begin{array}{l}\text { Decreased thiol-containing } \\
\text { proteins. Changes in spot } \\
\text { patterns consistent with greater } \\
\text { protein thiol oxidation in } \\
\text { response }\end{array}$ & $\begin{array}{l}{[100] \text { Tedesco et }} \\
\text { al., } 2010\end{array}$ \\
\hline M. galloprovincialis & Ag NPs & $\begin{array}{l}\text { MALDI-TOF- } \\
\text { TOF }\end{array}$ & $\begin{array}{l}\text { Up-regulation of: paramyosin, } \\
\text { catchin and major vault protein } \\
\text { in gills; Myosin heavy chain in } \\
\text { digestive gland }\end{array}$ & $\begin{array}{l}\text { [101] Gomes et } \\
\text { al., } 2013\end{array}$ \\
\hline M. galloprovincialis & $\mathrm{TiO}_{2} \mathrm{NPs}$ & qPCR & $\begin{array}{l}\text { Induction of metallothionein } \\
\text { gene expression in gills }\end{array}$ & $\begin{array}{l}\text { [102] D'Agata et } \\
\text { al., } 2014\end{array}$ \\
\hline M. edulis & $\mathrm{CuO}$ NPs & $\begin{array}{l}\text { 2-DE and } \\
\text { MALDI-TOF- } \\
\text { TOF }\end{array}$ & $\begin{array}{l}\text { General increase in protein } \\
\text { carbonyls and decrease in protein } \\
\text { thiols with increasing dose of } \\
\text { CuO NPs }\end{array}$ & $\begin{array}{l}\text { [103] Hu et al., } \\
2014\end{array}$ \\
\hline M. galloprovincialis & Ag NPs & qPCR & $\begin{array}{l}\text { No modification in gene } \\
\text { expression related to general and } \\
\text { oxidative stress, apoptosis, } \\
\text { immune system and morphology } \\
\text { after } 15 \text { days of exposure }\end{array}$ & $\begin{array}{l}\text { [104] Bebianno } \\
\text { et al., } 2015\end{array}$ \\
\hline M. edulis & $\mathrm{CuO}$ NPs & qPCR & $\begin{array}{l}\text { Greater effects of } \mathrm{CuO} \text { NPs on } \\
\text { GST, SOD, MT, Actin, ATP } \\
\text { synthase gene expressions }\end{array}$ & $\begin{array}{l}\text { [105] Châtel et } \\
\text { al., } 2018\end{array}$ \\
\hline M. galloprovincialis & $\begin{array}{c}\text { PE } \\
\text { microplastics }\end{array}$ & $\begin{array}{l}\text { Illumina } \\
\text { HiSeq2000 }\end{array}$ & $\begin{array}{c}\text { up-regulation of immune- } \\
\text { receptors and stress-related } \\
\text { proteins (glutathione peroxidase, } \\
\text { hsp70) }\end{array}$ & $\begin{array}{l}\text { [8] Détrée and } \\
\text { Gallardo- } \\
\text { Escárate, } 2018\end{array}$ \\
\hline Mytilus edulis & $\begin{array}{l}\text { HDPE and } \\
\text { PLA } \\
\text { microplastics }\end{array}$ & $\begin{array}{l}\text { HRAMS and } \\
\text { Dionex } \\
\text { Ultimate } 3000 \\
\text { HPLC }\end{array}$ & $\begin{array}{c}\text { Altered the hemolymph } \\
\text { proteome. Proteins involved in } \\
\text { immune regulation, } \\
\text { detoxification, metabolism and } \\
\text { structural devel-opment }\end{array}$ & $\begin{array}{l}\text { [106] Green et } \\
\text { al., } 2019\end{array}$ \\
\hline
\end{tabular}

